\title{
Status of the effectiveness of contact lens disinfectants in Malaysia against keratitis-causing pathogens
}

\author{
Farhat Abjani $^{\mathrm{a}}$, Naveed Ahmed Khan ${ }^{\mathrm{a}}$, Suk Yul Jung ${ }^{\mathrm{b}}$, Ruqaiyyah Siddiqui ${ }^{\mathrm{a}, *}$ \\ ${ }^{a}$ Department of Biological Sciences, School of Science and Technology, Sunway University, Malaysia \\ b Department of Biomedical Laboratory Science, Namseoul University, South Korea
}

\section{A R T I C L E I N F O}

\section{Article history:}

Received 28 June 2017

Received in revised form 15 August 2017

Accepted 11 September 2017

Available online $\mathrm{xxx}$

Keywords:

Acanthamoeba

Contact lens disinfectants

Bacteria

Eye pathogens

Keratitis

\begin{abstract}
A B S T R A C T
The aim of this study was (i) to assess the antimicrobial effects of contact lens disinfecting solutions marketed in Malaysia against common bacterial eye pathogens and as well as eye parasite, Acanthamoeba castellanii, and (ii) to determine whether targeting cyst wall would improve the efficacy of contact lens disinfectants. Using ISO 14729 Stand-Alone Test for disinfecting solutions, bactericidal and amoebicidal assays of six different contact lens solutions including Oxysept ${ }^{\circledR}$, AO SEPT PLUS, OPTI-FREE ${ }^{\circledR}$ pure moist ${ }^{\circledR}$, Renu $^{\circledR}$ fresh ${ }^{\text {TM }}$, FreshKon ${ }^{\circledR}$ CLEAR and COMPLETE RevitaLens ${ }^{\mathrm{TM}}$ were performed using Manufacturers Minimum recommended disinfection time (MRDT). The efficacy of contact lens solutions was determined against keratitis-causing microbes, namely: Pseudomonas aeruginosa, Methicillin-resistant Staphylococcus aureus, Streptococcus pyogenes, Streptococcus pneumoniae, and Acanthamoeba castellanii. In addition, using chlorhexidine as an antiamoebic compound and cellulase enzyme to disrupt cyst wall structure, we determined whether combination of both agents can enhance efficacy of marketed contact lens disinfectants against $A$. castellanii trophozoites and cysts, in vitro. The results revealed that all contact lens disinfectants tested showed potent bactericidal effects exhibiting 100\% kill against all bacterial species tested. In contrast, none of the contact lens disinfectants had potent effects against Acanthamoeba cysts viability. When tested against trophozoites, two disinfectants, Oxysept Multipurpose and AO-sept Multipurpose showed partial amoebicidal effects. Using chlorhexidine as an antiamoebic compound and cellulase enzyme to disrupt cyst wall structure, the findings revealed that combination of both agents in contact lens disinfectants abolished viability of $A$. castellanii cysts and trophozoites. Given the inefficacy of contact lens disinfectants tested in this study, these findings present a significant concern to public health. These findings revealed that targeting cyst wall by using cyst wall degrading molecules in contact lens disinfecting solutions will enhance their efficacy against this devastating eye infection.
\end{abstract}

\section{Introduction}

Microbial keratitis is a serious vision-threatening infection. Clinical features include redness, pain, tearing, blur vision and inflammation but symptoms vary depending on the causative agent (Ansari et al., 2013; Stapleton et al., 2007; Stapleton and Carnt, 2012). It is caused by viral, bacterial, fungal, and protist pathogens. Contact lens use is one of the important risk factors in contracting microbial pathogens leading to microbial keratitis. This is of particular concerns for less developed countries where the use of contact lenses is on the rise, with limited awareness of associated risks. For example, recently we tested the effects of contact lens disinfectants marketed in Pakistan against microbial pathogens. The findings revealed that none of the commercially available contact lens disinfectants were effective against eye par-

\footnotetext{
* Corresponding author. Department of Biological Sciences, School of Science and Technology, Sunway University, Selangor 47500, Malaysia.

Email address: ruqaiyyahs@sunway.edu.my (R. Siddiqui)
}

asite, Acanthamoeba castellanii (Lakhundi et al., 2014). In part, this was attributed to the ability of Acanthamoeba parasite to transform into a phenotypically distinct cyst form under harsh conditions (Marciano-Cabral and Cabral, 2003; Visvesvara et al., 2007; Siddiqui and Khan, 2012). Cysts are double-walled, hardy structures with minimal metabolic activity making it resistant to harsh environmental conditions as well as biocides, resulting in prolonged treatment and often leads to infection recurrence Aksozek et al., 2002; Turner et al., 2004; Khan, 2006). Given a plethora of contact lens disinfectants available in the market, it is important to assess their antimicrobial properties. Among a number of pathogens responsible for microbial keratitis, here we tested the efficacy of contact lens disinfectants marketed in Malaysia including Oxysept ${ }^{\circledR}$, AO SEPT PLUS, OPTI-FREE ${ }^{\circledR}$ pure moist ${ }^{\circledR}$, Renu ${ }^{\circledR}$ fresh ${ }^{\mathrm{TM}}$, FreshKon ${ }^{\circledR}$ CLEAR and COMPLETE RevitaLens $^{\mathrm{TM}}$ against common bacterial pathogens causing eye infections, including species of Pseudomonas, Staphylococcus, and Streptococcus, as well as leading eye parasite, Acanthamoeba castellanii. Moreover, as Acanthamoeba cyst walls are 
partly made of cellulose, we determined the inclusion of cellulase enzyme in contact lens disinfectants to degrade Acanthamoeba cyst walls in the improved efficacy of commercially available contact lens disinfectants.

\section{Material and methods}

All chemicals were purchased from Sigma Labs (Poole, Dorset, England) unless otherwise stated. The stock solution of chlorhexidine (CHX) was prepared in methanol and was stored at room temperature. We used cellulase enzyme isolated from Trichoderma viride (70 Units) and chlorhexidine dihydrochloride $(50 \mu \mathrm{M})$ in our experiments.

\subsection{Contact lens disinfecting solutions}

The type of contact lens disinfectants, the compositions and manufacturers' Minimum Recommended Disinfection Time (MRDT) are listed in Table 1. All disinfectants were examined before the expiry date recommended by the Manufacturer. Six different contact lens disinfectants included, Oxysept ${ }^{\circledR}$, AO SEPT PLUS, OPTI-FREE ${ }^{\circledR}$ pure moist ${ }^{\circledR}$, Renu ${ }^{\circledR}$ fresh ${ }^{\mathrm{TM}}$, FreshKon ${ }^{\circledR}$ CLEAR and COMPLETE RevitaLens ${ }^{\mathrm{TM}}$. These solutions were commonly marketed in Malaysia and were bought from nearby local pharmacy.

\subsection{Test organisms and growth conditions}

Among bacteria, Pseudomonas aeruginosa, Methicillin-resistant Staphylococcus aureus (MRSA), Streptococcus pyogenes, Streptococcus pneumoniae were tested in the present study. Methicillin-resistant Staphylococcus aureus is a clinical isolate from blood samples and was acquired from the Luton \& Dunstable Hospital NHS Foundation Trust, Luton, England. Pseudomonas aeruginosa was isolated from a clinical sample at the Aga Khan University hospital. Streptococcus pneumoniae was isolated from the blood culture of a pneumonia patient. $P$. aeruginosa and MRSA were grown overnight in a shaking incubator by inoculating bacterial culture in an enriched media, Luria-Bertani (LB) broth at $37{ }^{\circ} \mathrm{C}$, whereas $5 \% \mathrm{CO}_{2}$ was used to culture $S$. pneumoniae and $S$. pyogenes in brain-heart infusion (BHI) overnight at $37^{\circ} \mathrm{C}$. Although ISO 14729 requires the use of ATCC strains of bacterial organisms for testing, the bacterial strains used in this study were clinical isolates derived from human specimens and relevant to test contact lens disinfectants. Acanthamoeba castellanii belonging to the T4 genotype (American Type Culture Collection, ATCC 50492) was used. It is originally isolated from a patient suffering from Acanthamoeba keratitis. Acanthamoeba castellanii was cultured in a T-75 tissue culture flask in $10 \mathrm{~mL}$ Proteose peptone-Yeast extract-Glucose (PYG) medium $[0.75 \%(\mathrm{w} / \mathrm{v})$ proteose peptone, $0.75 \%(\mathrm{w} / \mathrm{v})$ yeast extract, and $1.5 \%(\mathrm{w} / \mathrm{v})$ glucose $]$ at $37{ }^{\circ} \mathrm{C}$ as previously described (Sissons et al., 2005). Before performing assays, Fresh PYG media was added in each flask approximately $17-20 \mathrm{~h}$ before, to obtain amoebae in the trophozoite form. In order to obtain cysts, Non-nutrient agar (NNA) plates were seeded with trophozoites aseptically. Next, plates were kept at $30{ }^{\circ} \mathrm{C}$ in an incubator for 14 days. Following this, $10 \mathrm{~mL}$ sterile PBS was added to each plate and cysts were scraped off by using a cell scraper. The cyst suspension was then centrifuged at $2000 \times g$ for $10 \mathrm{~min}$. Finally, the resultant pellet was resuspended in PBS after discarding the supernatant and cysts were counted using a haemocytometer.

\subsection{Bactericidal assays}

Bactericidal assays were performed to evaluate the bactericidal activity of various contact lens disinfectants against MRSA, Pseudomonas aeruginosa, Streptococcus pneumoniae and Streptococcus pyogenes. International Organization for Standardization (ISO) 14729 Stand Alone Test criteria for examining contact lens disinfectants efficacy was employed as described previously (Rosenthal et al., 2002). Briefly, the optical density of bacterial broth cultures was adjusted to 0.22 at $595 \mathrm{~nm}$ using a spectrophotometer. Next, $10^{6}$ colony forming units (CFU) of bacterial cultures were added in Eppendorf tubes. Tubes were centrifuged at $12,000 \times g$ for $2 \mathrm{~min}$ to pellet bacterial CFU. The supernatant was aspirated followed by addition of $200 \mu \mathrm{L}$ of six different contact lens disinfectants to resuspend bacteria. Following $6 \mathrm{~h}$ of incubation, bacteria were enumerated by plating as described previously (Abjani et al., 2016). Bacteria incubated with PBS alone and bacteria incubated with gentamicin $\quad 100 \mu \mathrm{g}$ per $\mathrm{mL}$ were used

Table 1

List of contact lens disinfectants tested in the present study together with their ingredients, manufacturer, type of solution and Minimum recommended disinfection time (MRDT).

\begin{tabular}{|c|c|c|c|c|}
\hline Solution & Ingredients & Manufacturer & $\begin{array}{l}\text { Minimum recommended } \\
\text { disinfection time } \\
\text { (MRDT) }\end{array}$ & Type of solution \\
\hline Oxysept ${ }^{(R)}$ & $3 \%$ Hydrogen peroxide & $\begin{array}{l}\text { Abbot Medical Optics, } \\
\text { Hangzhou }\end{array}$ & $6 \mathrm{~h}$ & $\begin{array}{l}\text { Hydrogen peroxide } \\
\text { system }\end{array}$ \\
\hline AO SEPT PLUS & $3 \%$ Hydrogen peroxide & $\begin{array}{l}\text { Alcon laboratories, Inc. } \\
\text { Fort Worth, USA. }\end{array}$ & $6 \mathrm{~h}$ & $\begin{array}{l}\text { Hydrogen peroxide } \\
\text { system }\end{array}$ \\
\hline $\begin{array}{l}\text { OPTI-FREE } \\
\text { PureMoist }^{\circledR}\end{array}$ & $\begin{array}{l}\text { POLYQUAD } \\
\text { dimethylamine) } 0.0006 \% \text { preservatives }\end{array}$ & $\begin{array}{l}\text { Alcon laboratories, Inc. } \\
\text { Fort Worth, Texas } \\
\text { USA. }\end{array}$ & $6 \mathrm{~h}$ & $\begin{array}{l}\text { Multi-purpose } \\
\text { Disinfecting } \\
\text { solution }\end{array}$ \\
\hline $\begin{array}{l}\text { COMPLETE } \\
\text { RevitaLens }^{\mathrm{TM}}\end{array}$ & $\begin{array}{l}\text { Alexidine dihydrochloride } 0.00016 \% \text {, Polyquaternium- } 10.0003 \% \text {, boric acid, } \\
\text { sodium borate decahydrate, TETRONIC } 904 \text {, edetate disodium, sodium } \\
\text { citrate, sodium chloride and purified water. }\end{array}$ & $\begin{array}{l}\text { Abbot Medical Optics, } \\
\text { Hangzhou }\end{array}$ & $6 \mathrm{~h}$ & $\begin{array}{l}\text { Multi-purpose } \\
\text { Disinfecting } \\
\text { solution }\end{array}$ \\
\hline Renu $^{(\mathbb{}}$ fresh $^{\mathrm{TM}}$ & $\begin{array}{l}\text { HYDRANATE (hydroxyalkylphosphonate), boric acid, edetate disodium, } \\
\text { poloxamine, sodium borate and sodiumchloride, preserved with DYMEDTM } \\
\text { (polyaminopropyl biguanide) } 0.0001 \%\end{array}$ & $\begin{array}{l}\text { Baush \& Lomb } \\
\text { Greenville, USA. }\end{array}$ & $4 \mathrm{~h}$ & $\begin{array}{l}\text { Multi-purpose } \\
\text { solution }\end{array}$ \\
\hline $\begin{array}{l}\text { FreshKon }^{(B)} \\
\text { CLEAR }\end{array}$ & $\begin{array}{l}\text { Sodium and Potassium chloride, Disodium Edetate, Polyhexanide, Poloxamer, } \\
\text { Hypromellose and Sodium Phosphate Buffer }\end{array}$ & $\begin{array}{l}\text { Oculus private limited, } \\
\text { Singapore }\end{array}$ & $6 \mathrm{~h}$ & $\begin{array}{l}\text { Multi-purpose } \\
\text { solution }\end{array}$ \\
\hline
\end{tabular}


as negative and positive controls. All experiments were performed several times in duplicate.

\subsection{Amoebicidal assays}

The amoebicidal assays were performed as previously described (Abjani et al., 2016). Briefly, contact lens disinfectants were incubated with $5 \times 10^{5}$ amoebae (final volume: $200 \mu \mathrm{L}$ ) for $6 \mathrm{~h}$ at room temperature as per Manufacturers' instructions. In some experiments, amoebae were incubated with contact lens disinfectants containing chlorhexidine $(50 \mu \mathrm{M})$ and cellulase (70 units). Next, 0.1\% Trypan blue was added to enumerate number of viable trophozoites by Trypan blue exclusion assay (dead cells having porous cell membrane allows Trypan blue entry and as a result cells appear blue whereas live cells remain unstained). To further confirm the viability of amoebae, amoebae were centrifuged at $2000 \times g$ for 5 min post-treatment to remove contact lens disinfectants, cellulase and residual drugs. The resultant pellet was resuspended in $200 \mu \mathrm{L}$ of PYG and was re-inoculated in 96-well plates for $72 \mathrm{~h}$ at $30^{\circ} \mathrm{C}$. Additionally, amoebae trophozoites were inoculated in Roswell Park Memorial Institute-1640 (RPMI) medium alone as a control. All experiments were conducted several times in duplicate. The data are presented as mean \pm standard error.

\subsection{Cysticidal assays}

Cysticidal assays were performed as described above. Briefly, cysts $\left(5 \times 10^{4}\right.$ cyst $)$ were incubated with contact lens disinfectants, along with chlorhexidine $(50 \mu \mathrm{M})$ and cellulase (70 units) for $6 \mathrm{~h}$ at room temperature as above, followed by Trypan blue exclusion assay and enumeration of dead cells using haemocytometer counting. The viability of amoebae cysts was further confirmed using inoculating cysts, post-treatment, in fresh PYG as described above in 96-well plates for $72 \mathrm{~h}$ at $30^{\circ} \mathrm{C}$. For negative control, cysts were inoculated in Roswell Park Memorial Institute-1640 (RPMI) medium alone. All experiments were conducted several times in duplicate. The data are presented as mean \pm standard error.

\section{Results}

\subsection{Bactericidal effect of multipurpose contact lens disinfectant against $P$. aeruginosa and MRSA, Streptococcus pyogenes and Streptococcus pneumoniae}

To evaluate the bactericidal effects of contact lens disinfectants on $P$. aeruginosa and MRSA, assays were performed by inoculating $10^{6}$ bacteria in $200 \mu \mathrm{L}$ of contact lens disinfectants. The results revealed that all six contact lens disinfectants: Oxysept ${ }^{\circledR}$, AO SEPT PLUS, OPTI-FREE ${ }^{\circledR}$ PureMoist, COMPLETE RevitaLens, Renu ${ }^{\circledR}$ fresh and FreshKon ${ }^{\circledR}$ CLEAR exhibited potent bactericidal effects against MRSA (Fig. 1A), P. aeruginosa (Fig. 1B), Streptococcus pyogenes (Fig. 1C), and Streptococcus pneumoniae (Fig. 1D) within Manufacturer's Minimum Recommended Disinfection time (MRDT) and no bacterial colonies were observed. For positive controls, bacteria incubated with $100 \mu \mathrm{g}$ per $\mathrm{mL}$ of gentamicin abolished bacterial viability. When incubated alone, bacteria exhibited growth compared with the original inoculum.

\subsection{Combination of cellulase and chlorhexidine improved efficacy of contact lens disinfectants against A. castellanii trophozoites}

To determine the effects of contact lens disinfectants against Acanthamoeba castellanii trophozoites, amoebae were incubated with contact lens solutions. The results showed that all four multipurpose Contact lens disinfectants (without hydrogen peroxide) OPTI-FREE ${ }^{\circledR}$ pure moist ${ }^{\circledR}$, Renu ${ }^{\circledR}$ fresh $^{\mathrm{TM}}$, FreshKon ${ }^{\circledR}$ CLEAR and COMPLETE RevitaLens $^{\mathrm{TM}}$ were ineffective in killing $A$. castellanii trophozoites. There was no difference between the original inoculum $\left(5 \times 10^{5}\right.$ amoebae $)$ and the number of viable Acanthamoeba post-treatment, $4.29 \times 10^{5} \pm 3.55 \times 10^{4}, \quad 4.07 \times 10^{5} \pm 7.3 \times 10^{4}$, $4.07 \times 10^{5} \pm 7.7 \times 10^{4}$ and $3.67 \times 10^{5} \pm 2.0 \times 10^{3}$ using OPTI-FREE ${ }^{\circledR}$ pure moist ${ }^{\circledR}$, Renu $^{\circledR}$ fresh $^{\mathrm{TM}}$, FreshKon ${ }^{\circledR}$ CLEAR and COMPLETE RevitaLens ${ }^{\mathrm{TM}}$ respectively (Fig. 2). Moreover, when amoebae were inoculated in fresh PYG post-treatment, viable trophozoites emerged within $24 \mathrm{~h}$. In contrast, hydrogen peroxide containing disinfectants showed partial amoebicidal effects and the number of viable amoeba was $7.35 \times 10^{4} \pm 3.55 \times 10^{4}, 4.95 \times 10^{4} \pm 5.5 \times 10^{3}$ for Oxysept $^{\circledR}$, and AO SEPT PLUS respectively (Fig. 2).

To determine whether the addition of cellulase and chlorhexidine at micromolar concentration improve the efficacy of contact lens disinfectants, cellulase enzyme was added at $70 \mu \mathrm{M}$. The results revealed that the addition of cellulase showed no effect on the viability of trophozoites and after $6 \mathrm{~h}$ of incubation the number of viable amoebae was $3.28 \times 10^{5} \pm 3.5 \times 10^{3}$. When cellulase was combined with contact lens disinfectants, OPTI-FREE ${ }^{\circledR}$ pure moist $^{\circledR}$, Renu $^{\circledR}$ fresh $^{\mathrm{TM}}$, FreshKon ${ }^{\circledR}$ CLEAR and COMPLETE RevitaLens ${ }^{\mathrm{TM}}$ the number of viable amoeba was $2 \times 10^{5} \pm 2 \times 10^{3}, 2.68 \times 10^{5} \pm 4.0 \times 10^{4}$, $2.67 \times 10^{5} \pm 1.1 \times 10^{4}$ and $2.66 \times 10^{5} \pm 1.5 \times 10^{4}$ respectively but upon re-inoculation in fresh PYG, viable trophozoites emerged within $72 \mathrm{~h}$. Similarly, chlorhexidine alone (up to $50 \mu \mathrm{M}$ ) showed potent amoebicidal effects on the viability of $A$. castellanii trophozoites.

Notably, contact lens disinfectants, OPTI-FREE ${ }^{\circledR}$ pure moist ${ }^{\circledR}$, Renu ${ }^{\circledR}$ fresh ${ }^{\mathrm{TM}}$, FreshKon ${ }^{\circledR}$ CLEAR and COMPLETE RevitaLens ${ }^{\mathrm{TM}}$ in combination with cellulase (70 units) and chlorhexidine $(50 \mu \mathrm{M})$ abolished viability of $A$. castellanii trophozoites within $6 \mathrm{~h}$ of incubation and the number was reduced to $3.85 \times 10^{4} \pm 1.2 \times 10^{4}$, $1.50 \times 10^{4} \pm 4.00 \times 10^{3}, 3.10 \times 10^{4} \pm 9 \times 10^{3}$ and $3 \times 10^{4} \pm 1 \times 10^{3}$ respectively (Fig. 2). Post-treatment, amoebae were unable to revive in fresh PYG medium even after $72 \mathrm{~h}$ (data not shown). Amoebae in RPMI as negative control and in methanol as solvent control for chlorhexidine showed no amoebicidal effect and the number was $5.52 \times 10^{5} \pm 6.5 \times 10^{4}$ and $4.01 \times 10^{5} \pm 5.3 \times 10^{4}$ respectively.

\subsection{Addition of cellulase and chlorhexidine improved efficacy of contact lens disinfectants against cysts of $A$. castellanii}

Cysticidal assays were performed to evaluate the efficacy of contact lens disinfectants. The results revealed that all four multipurpose Contact lens disinfectant (without hydrogen peroxide) OPTI-FREE ${ }^{\circledR}$ pure moist ${ }^{\circledR}$, Renu ${ }^{\circledR}$ fresh $^{\mathrm{TM}}$, FreshKon ${ }^{\circledR}$ CLEAR and COMPLETE RevitaLens ${ }^{\mathrm{TM}}$ were ineffective in killing $A$. castellanii cyst (Fig. 3), and viable amoebae emerged when inoculated in fresh PYG compared with the original inoculum (dotted line). Post-treatment, viable trophozoites emerged within $72 \mathrm{~h}$. Hydrogen peroxide containing disinfectants (Oxysept $\left.{ }^{(}\right)$and AO SEPT PLUS) showed partial $\begin{array}{llll}\text { cysticidal } & \text { effects } & \text { (Fig. } & 3 \text { ). }\end{array}$ 
A

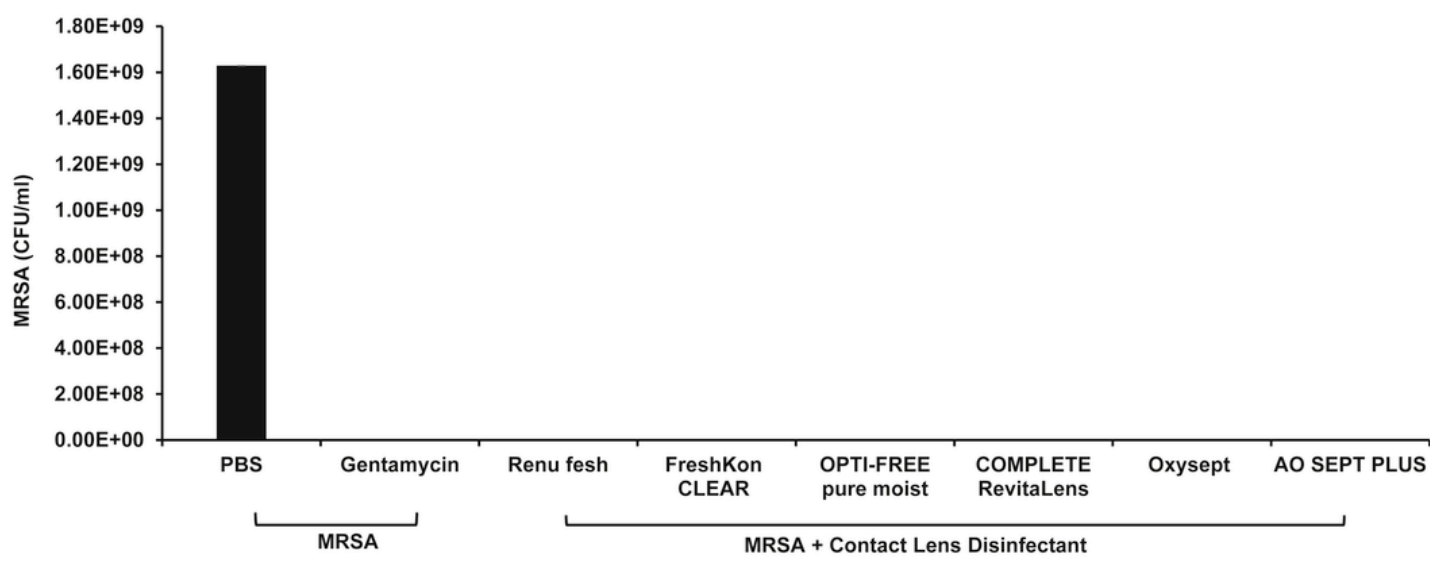

B

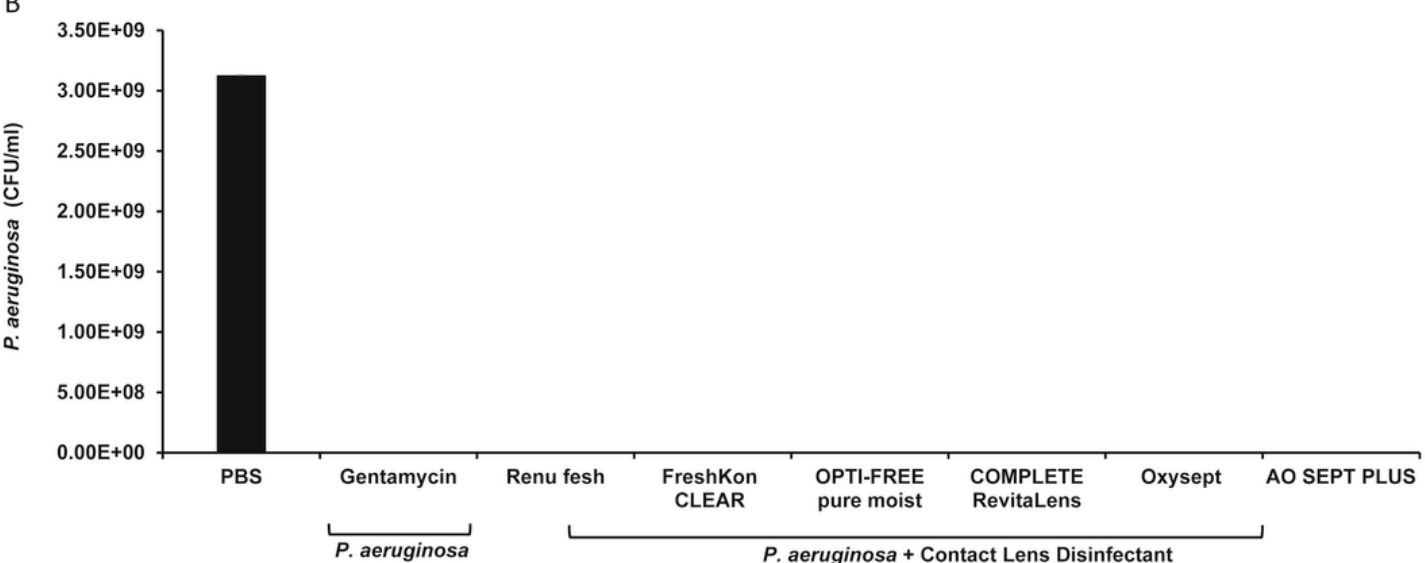

C

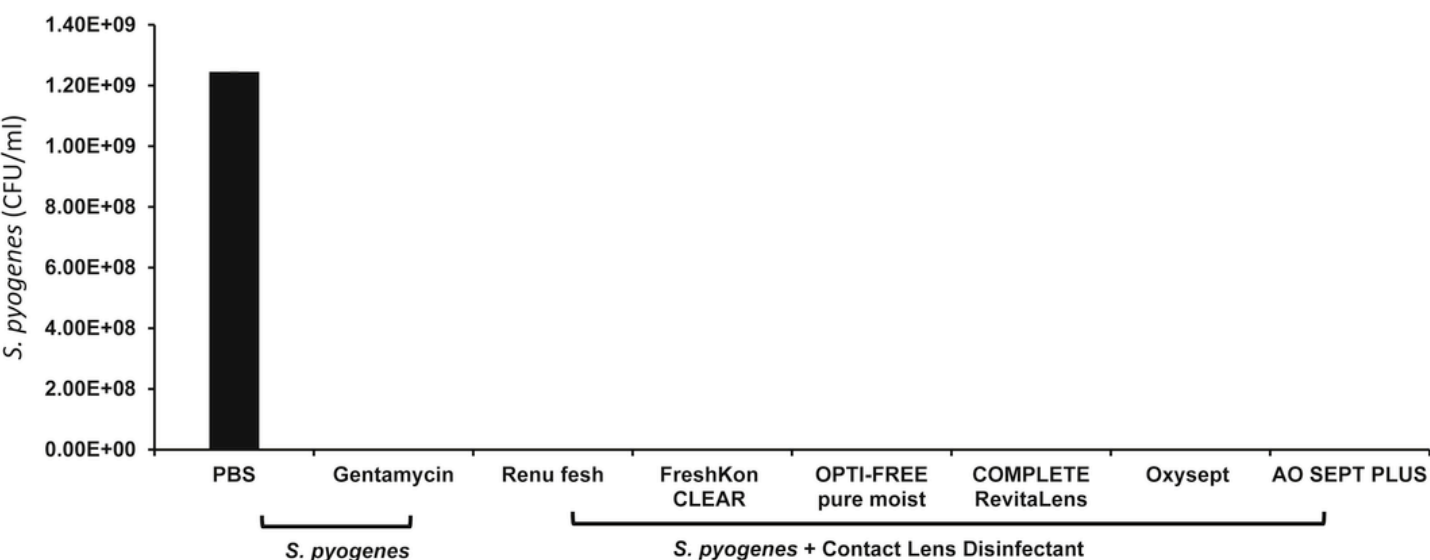

Fig. 1. Commonly used contact lens disinfectants marketed in Malaysia were tested including Oxysept (OS), AO SEPT PLUS (AO SP), OPTI-FREE pure moist (OF PM), Renu fresh (RF), FreshKon CLEAR (FKC) and COMPLETE RevitaLens (CRL) against MRSA (A), P. aeruginosa (B), Streptococcus pyogenes (C), and Streptococcus pneumoniae (D) using Manufacturer's Minimum Recommended Disinfection time (MRDT) as described in Materials and Methods. $100 \mu \mathrm{g} / \mathrm{mL}$ of gentamicin was used as a positive control, while bacteria incubated in PBS alone were used as a negative control. All six disinfectants tested abolished bacterial viability. The data is representative of several experiments performed in duplicate as expressed as the mean \pm standard error.

enzyme when used at $70 \mu \mathrm{M}$ showed no significant effect and the number was $1.72 \times 10^{5} \pm 1.69 \times 10^{4}$. However, combination of cellulase and chlorhexidine with contact lens disinfectants abolished viability of $A$. castellanii cysts and amoebae were unable to revive when inoculated in fresh PYG (Fig. 3).

\section{Discussion}

Keratitis is a vision-threatening disease of the eye often associated with the use of contact lens (Mascarenhas et al., 2014). If not treated promptly, it can lead to permanent vision impairment. Improper contact lens hygiene, use of homemade saline 
D

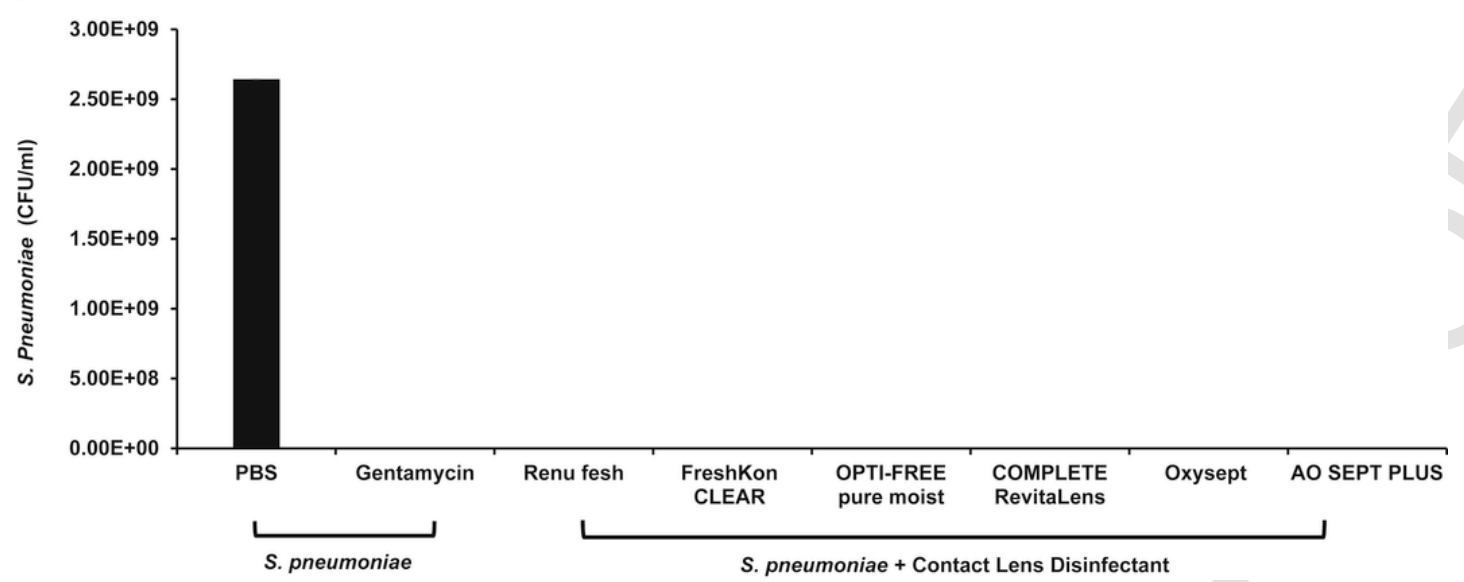

Fig. 1. (Continued)

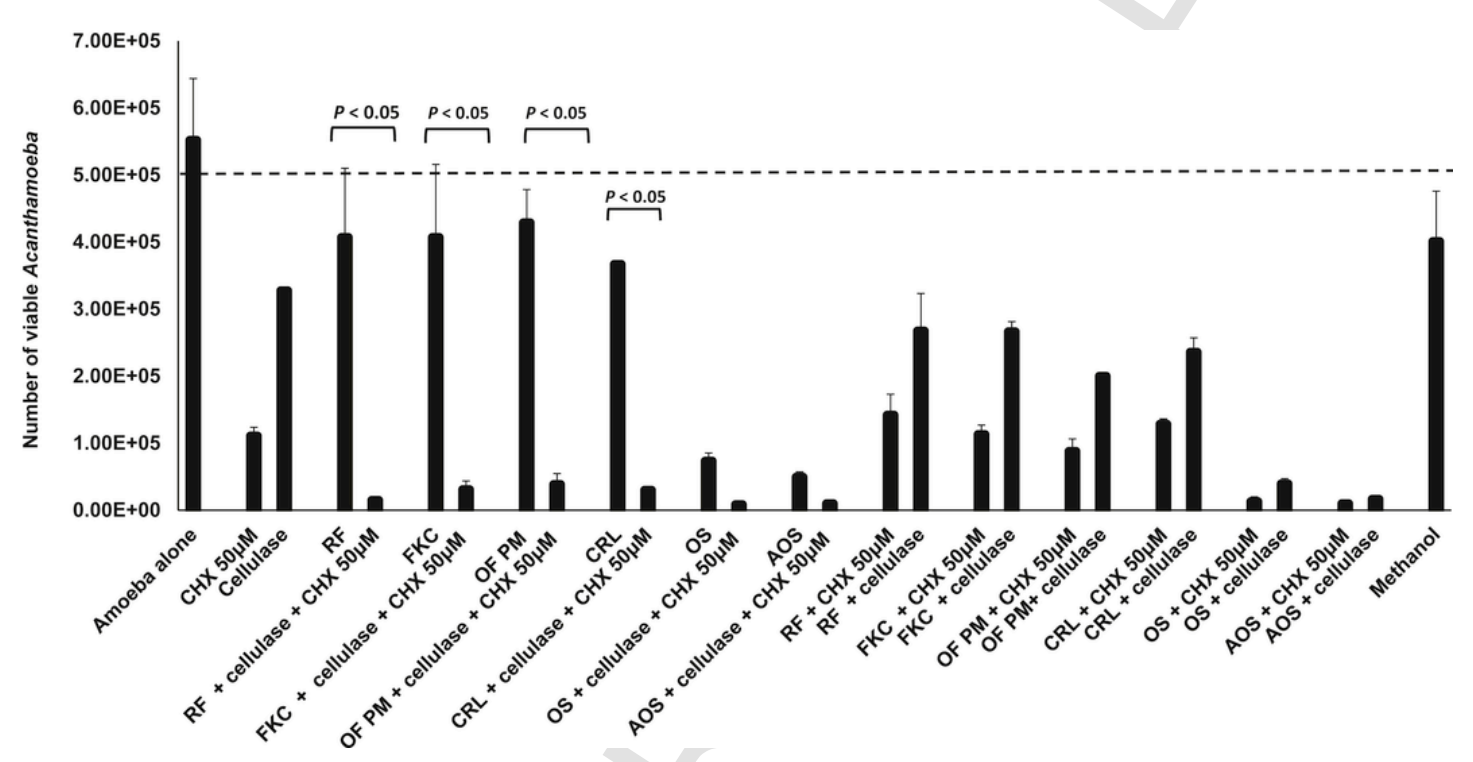

Fig. 2. Contact lens disinfectants including Oxysept (OS), AO SEPT PLUS (AO SP), OPTI-FREE pure moist (OF PM), Renu fresh (RF), FreshKon CLEAR (FKC) and COMPLETE RevitaLens (CRL) were tested against $A$. castellanii trophozoites as described in Materials and Methods. Note that none of the contact lens disinfectants destroyed amoebae effectively. However, addition of chlorhexidine (CHX) and cellulase to contact lens disinfectant abolished $A$. castellanii viability as compared to the contact lens disinfectant alone. The dotted line represents initial inoculum of trophozoites. The data is expressed as the mean \pm standard error of several experiments performed in duplicate.

solutions for cleaning and storing lenses as well as using expired disinfectants further leads to an increase risk of microbial keratitis among contact lens wearers (Stapleton et al., 2007; Stapleton and Carnt, 2012; Lorenzo-Morales et al., 2013). In this study, we determine the effectiveness of contact lens disinfectants available commercially in Malaysia against common bacterial eye pathogens and corneal parasite, Acanthamoeba castellanii. Our findings revealed that all contact lens disinfectants tested exhibited potent bactericidal effects against species tested. However, none of the contact lens disinfectants completely destroyed $A$. castellanii trophozoites and cyst. These findings are consistent with several recent studies indicating that marketed contact lens disinfectants are ineffective in completely destroying amoebae (Kolar et al., 2015; Padzik et al., 2014; Polat et al., 2007; Ustüntürk and Zeybek, 2014). In particular, there show limited efficacy against cysts. Chlorhexidine at $50 \mu \mathrm{M}$ concentration destroyed amoeba within $6 \mathrm{~h}$ of incubation time at room temper- ature. However, cellulase treatment had no effect on the viability of amoebae and parasites re-emerged as viable trophozoites upon re-inoculation in PYG. In contrast, a combination of chlorhexidine and cellulase together with contact lens disinfectants proved highly effective in killing both $A$. castellanii cyst and trophozoites. Our findings showed that targeting the cellulose synthesis pathway inhibits Acanthamoeba switching into the cyst form. This is likely due to the ability of cellulase to destroy cyst walls by degrading cellulose, allowing chlorhexidine to target the resident trophozoite within and ultimately leading to its death. This is consistent with our previous findings which showed that the addition of cellulase enzyme together with chlorhexidine enhanced the efficacy of contact lens solutions marketed in Pakistan (Abjani et al., 2016). As cellulose synthesis is limited to plants, yeast, and some bacteria, it is likely to have minimal side effects against human cells. Overall, the results obtained from our previous as well as the present study clearly demonstrate that there 


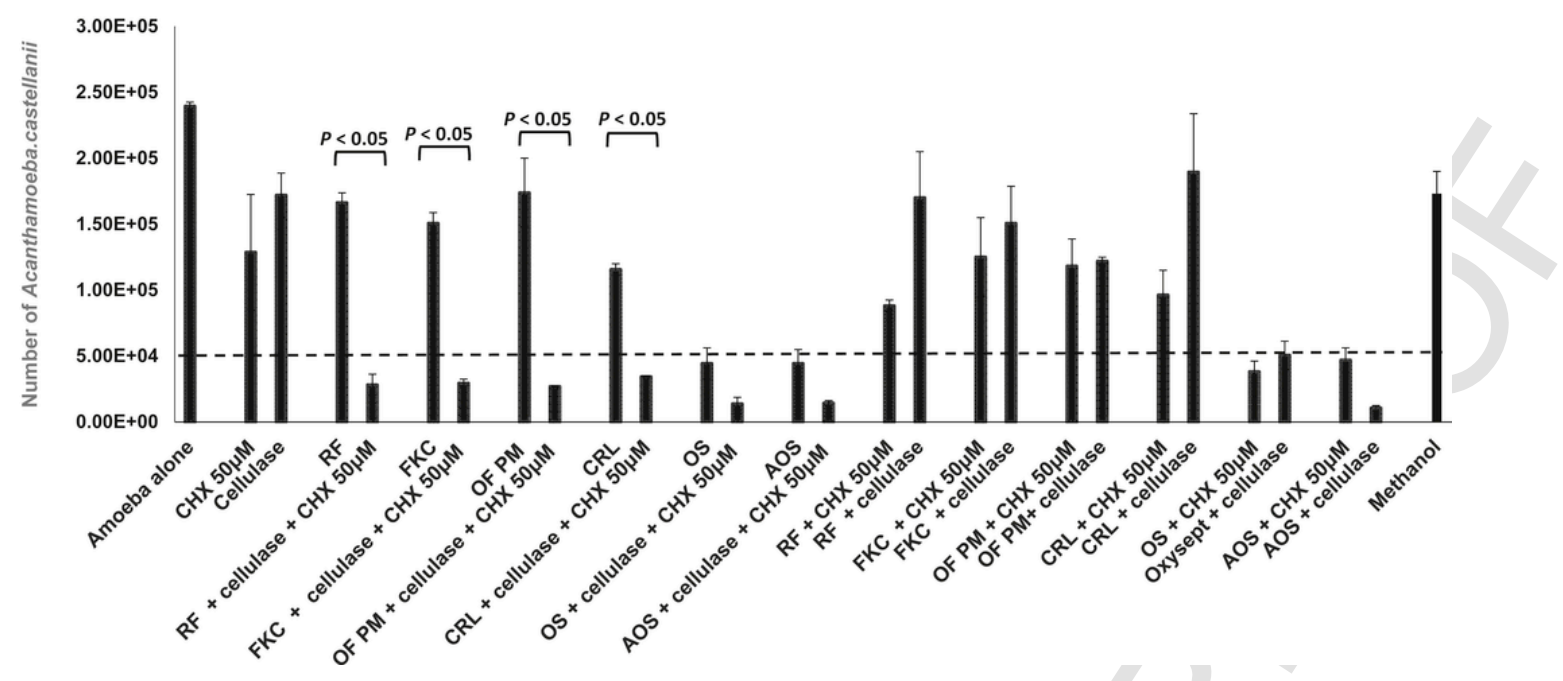

Fig. 3. Contact lens disinfectants including Oxysept (OS), AO SEPT PLUS (AO SP), OPTI-FREE pure moist (OF PM), Renu fresh (RF), FreshKon CLEAR (FKC) and COMPLETE RevitaLens (CRL) were tested against $A$. castellanii cysts as described in Materials and Methods. Note that none of the contact lens disinfectants destroyed amoebae cysts. However, addition of chlorhexidine (CHX) and cellulase to contact lens disinfectant abolished A. castellanii viability as compared to the contact lens disinfectant alone. The dotted line represents initial inoculum of cysts. The data is expressed as the mean \pm standard error of several experiments performed in duplicate.

is a need for an improved contact lens disinfectant against Acanthamoeba castellanii. As cysts are partly made of cellulose, degradation of cellulose by cellulase enzyme and chlorhexidine is a promising strategy in targeting A. castellanii trophozoites as well as cysts. Our findings also highlight the ineffectiveness of commercially available contact lens disinfectants in Malaysia that present a major health risk to the public. We propose that a similar strategy can be employed in the improved treatment of Acanthamoeba keratitis that can normally last up to a year and often complicated due to infection recurrence, however intensive research is needed over the next few years to determine the translational value of these findings.

\section{Conflicts of interest}

None to declare.

\section{Uncited references}

Lakhundi et al., 2014.

\section{Acknowledgments}

The authors are grateful for the kind support provided by Sunway University, Malaysia and Lancaster University, UK.

\section{References}

Abjani, F., Khan, N.A., Yousuf, F.A., Siddiqui, R., 2016. Targeting cyst wall is an effective strategy in improving the efficacy of marketed contact lens disinfecting solutions against Acanthamoeba castellanii cysts. Cont. Lens Anter Eye 39 (3), $239-243$.

Aksozek, A., McClellan, K., Howard, K., Niederkorn, J.Y., Alizadeh, H., 2002. Resistance of Acanthamoeba castellanii cysts to physical, chemical, and radiological conditions. J. Parasitol. 88 (3), 621-623.

Ansari, Z., Miller, D., Galor, A., 2013. Current thoughts in fungal keratitis: diagnosis and treatment. Curr. Fungal Infect. Rep. 7, 209-218.

Clarke, B., Sinha, A., Parmar, D.N., Sykakis, E., 2012. Advances in the diagnosis and treatment of Acanthamoeba keratitis. J. Ophthalmol.Article ID: 484892.
Khan, N.A., 2006. Acanthamoeba: biology and increasing importance in human health. FEMS Microbiol. Rev. 30 (4), 564-595.

Kolar, S.S., Manarang, J.C., Burns, A.R., Miller, W.L., McDermott, A.M., Bergmanson, J.P., 2015. Contact lens care solution killing efficacy against Acanthamoeba castellanii by in vitro testing and live-imaging. Cont. Lens Anterior Eye 38 (6), $442-450$.

Lakhundi, S., Khan, N.A., Siddiqui, R., 2014. Inefficacy of marketed contact lens disinfection solutions against keratitis-causing Acanthamoeba castellanii belonging to the T4 genotype. Exp. Parasitol. 141, 122-128.

Lorenzo-Morales, J., Martín-Navarro, C.M., López-Arencibia, A., Arnalich-Montiel, F., Piñero, J.E., Valladares, B., 2013. Acanthamoeba keratitis: an emerging disease gathering importance worldwide? Trends Parasitol. 29 (4), 181-187.

Marciano-Cabral, F., Cabral, G., 2003. Acanthamoeba spp. as agents of disease in humans. Clin. Microbiol. Rev. 16 (2), 273-307.

Mascarenhas, J., Lalitha, P., Prajna, N.V., Srinivasan, M., Das, M., D'Silva, S.S., Oldenburg, C.E., Borkar, D.S., Esterberg, E.J., Lietman, T.M., Keenan, J.D., 2014 Acanthamoeba, fungal, and bacterial keratitis: a comparison of risk factors and clinical features. Am. J. Ophthalmol. 157 (1), 56-62.

Padzik, M., Chomicz, L., Szaflik, J.P., Chruścikowska, A., Perkowski, K., Szaflik, J., 2014. In vitro effects of selected contact lens care solutions on Acanthamoeba castellanii strains in Poland. Exp. Parasitol. (145 Suppl.), S98-S101.

Polat, Z.A., Vural, A., Cetin, A., 2007. Efficacy of contact lens storage solutions against trophozoite and cyst of Acanthamoeba castellanii strain 1BU and their cytotoxic potential on corneal cells. Parasitol. Res. 101 (4), 997-1001.

Siddiqui, R., Khan, N.A., 2012. Biology and pathogenesis of Acanthamoeba. Parasit. Vectors 5 (1), ID: 6.

Sissons, J., Kim, K.S., Stins, M., Jayasekera, S., Alsam, S., Khan, N.A., 2005. Acanthamoeba castellanii induces host cell death via a phosphatidylinositol 3-kinase-dependent mechanism. Infect. Immun. 73 (5), 2704-2708.

Stapleton, F., Keay, L.J., Sanfilippo, P.G., Katiyar, S., Edwards, K.P., Naduvilath, T., 2007. Relationship between climate, disease severity, and causative organism for contact lens-associated microbial keratitis in Australia. Am. J. Ophthalmol. 144, 690-698.

Stapleton, F., Carnt, N., 2012. Contact lens-related microbial keratitis: how have epidemiology and genetics helped us with pathogenesis and prophylaxis. Eye (Lond) 26, 185-193.

Turner, N.A., Russell, A.D., Furr, J.R., Lloyd, D., 2004. Resistance, biguanide sorption and biguanide-induced pentose leakage during encystment of Acanthamoeba castellanii. J. Appl. Microbiol. 96 (6), 1287-1295.

Ustüntürk, M., Zeybek, Z., 2014. Amoebicidal efficacy of a novel multi-purpose disinfecting solution: first findings. Exp. Parasitol. (145 Suppl), S93-S97.

Visvesvara, G.S., Moura, H., Schuster, F.L., 2007. Pathogenic and opportunistic free-living amoebae: Acanthamoeba spp., Balamuthia mandrillaris, Naegleria fowleri, and Sappinia diploidea. FEMS Immunol. Med. Microbiol. 50, 1-26. 